\title{
De nordslesvigske Optanter.
}

Af H. P. Hanssen-Nørremølle.

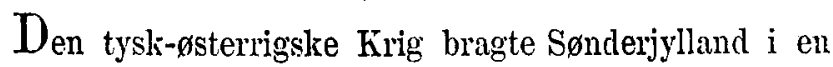
højst ejendommelig Stilling. Hertugdømmerne blev indlemmede i Preussen, men Pragfredens $§ 5$ gav Nordslesvig Ret til Gjenforening med Danmark. Under disse Forhold anede ingen, at Nordslesvig endnu skulde være forenet med Preussen, når 25 Års-Dagen for Dybbøls Fald oprandt. De danske Sønderjyder følte sig tyertimod alle som én overbeviste om, at Gjenforeningen med Moderlandet var nær forestående.

Wienerfredens \& 19 gav Hertugdømmernes Beboere Ret til at vælge frit mellem dansk og tysk Undersåtsforhold indtil d. 16. Novbr. 1870. Det var under den givne Situation meningsløst at underksste sig den treinige preussiske Militærtjeneste, og da den første Militærudskrivning fandt Sted i 1867, opterede derfor næsten wlle værnepligtige Nordslesvigere for Danmark, Senere hen på Året, da det ældre Mandskab fra 24-38 Års̈ Alderen sammenkaldtes for at aflægge Faneeden $0 \mathrm{~g}$ indrulleres $i$ den preussiske Reserve, opterede endnu flere for Danmark, og de, der foreløbig faldt til Føje, valgte på få Undtagelser nær dansk Undersaitsforhold lige før den fransktyske Krigs Udbrud. Wienerfreden bestemte, at Optanterne ikke mîtte „forulempes på Person eller Ejendom på Grund 
af deres frie Valg," men desuagtet blev de fra første Færd af til Hobe udviste af den preussiske Regering, og forst i Halvfjerdserne var derfor næsten hele den mandlige nordslesvigske Ungdom landtygtig.

De uljemlede Masse-Udvisninger gav Anledning til utallige Klager, indtil Dammark og Preussen 1872 afsluttede en Overenskomst om Optanternes retslige Stilling. Denne Overenskomst, den si̊kaldte Åbenrå-Konvention, gav Optanterne Ret til at vende tilbage og tage varigt Ophold i Sønderjylland, hvis de ikke gav Anledning til grundede Klager, specielt ved at vise fjendtligt Sindelag mod den preussiske Stat.

I de forlgende $\mathrm{Ar}$ vendte Optanterne $\mathrm{i}$ Tusendvis tilbage til Sønderjylland, hvor de fleste efter Hånden bosatte sig som danske Borgere. Men inden ret længe foretog den preussiske Regering nye Udvisninger, som, da der i Reglen ikke forelå vægtige Grunde, blot motiveredes med, at Politiet fandt de Pågjældende „lästig“". Udvisningerne, som $\dot{A} r$ for $\AA r$ blev lyppigere, voldte megen Fortræd; de pdelagde manges Livslykke og lammede den fri Handlekraft ved at fremkalde en almindelig Følelse af Usikkerhed.

Således var Stillingen, da Traktaten af 11. Octbr. 1878 erklærede Pragfredens $\S 5$ for ophævet. Tolv År i Forvejen havde Grev Bismarck sagt, at Preussen vilde opfylde sine traktatmæssige Forpligtelser og udføre Pragfredens Bestemmelser. Optionen i Tredserne var foregået i Tillid hertil, og Regeringen burde derfor nu have stillet Optanterne overfor et nyt Valg. Derved vilde Optantspørgs-. målet have fundet én under de givne Forhold tilfredsstillende Løsning for alle Parter. Men Regeringen gjorde ikke de hårdt skuffede Optanter den mindste Indrømmelse; 
den lagde tvertimod Hindringer i Vejen for deres Gjenoptagelse i preussisk Undersåtsforhold, og Spørgsmålet fik derfor Lejlighed til at frembyde nye Vanskeligheder.

I Slutningen af Halvfjerdserne nåede Optanternes ældste Sønner den værnepligtige Alder, og da de underordnede Myndigheder var i T'vivl om deres statsretlige Stilling, optoges de flere Steder i den tyske Lægdsrulle. Det gav selvfølgelig Anledning til nye Klager og Klagerne til nye Forhandlinger mellem de to Landes Regeringer. Resultatet blev, at den preussiske Regering i $18 \% 9$ formelt anerkjendte alle før d. 16. Novbr. 1864 fødte Børn af Optanter som danske Statsborgere. I de følgende År aftjente Optanternes Sønner i Henhold til denne Afgjørelse deres Værnepligt i Danmark, men da de derefter for. største Delen atter tog varigt Ophold i Sønderjylland, gav det den preussiske Regering Anledning til at foretage en Svingning.

Ved Nytårstid 1883 indfandt den tyske Gesandt i Kjøbenhavn sig i Udenrigsministeriet, hvor han mundtlig meddelte Direktøren, at alle i Slesvig og Holsten boende danıske Statsborgere fremtidig vilde blive uilviste, efter Hånden som de nåede den værnepligtige Alder, med mindre de. Iod sig optage $\mathrm{i}$ den tyske Lægdsrulle og derefter naturalisere. Den danske Regering søgte forgjæves at standse den bebudede Forholdsregel. Ti Dage senere kundgjorde Lokaløvrighederne i Nordslesvig, at alle i 1863 fødte danske Undersaitter vilde blive udviste, siffremt de ikke den 1. Febr. var optagne $\mathrm{i}$ den tyske Lægdsrulle. Da den danske Gesandt i Berlin til sin store Overraskelse erfarede af Aviserne, at Forholdsreglen var trådt i Kraft, fremhævede han skarpt dens Uretfærdighed overfor de før 
d. 16. Novbr. 1864 fødte Sønner af Optanter. Han påviste disse unge Mænds særegne statsretlige Stilling. De var danske Borgere $\mathrm{i}$ Henhold til Wienerfreden, og den preussiske Regering havde formelt anerkjendt, at ÅbenråKonventionen gav dem Ret til varigt Ophold i Sønderjylland. - Fyrst Bismarcks Svar herpå var, at Overenskomsterne med Danmark i hvert Fald ikke indrømmede Optanterne større Ret end alle andre Udlændinge, hvorfor de til enhver 'Tid kunde udvises.

Imidlertid måtte alle tyveårige danske Statsborgere i Nordslesvig skyndsomst træffe deres Valg. De fleste rømte frivillig Landet, thi Regeringen nægtede at optage Fædrene i preussisk Undersåtsforhold, og mange havde Brødre i den danske Hær. En Del faldt til Føje og lod sig optage i den tyske Lægdsrulle, men kun fì afventede Udvisningsordren. Forholdene i Norlslesvig forvirredes derved endnu mere, men den preussiske Regering fastholdt fuldt ud sit én Gang indtagne Standpunkt, og den er siden da giet lionsekvent frem. Optanternes Sønner tvinges - efter Hånden som de når den værnepligtige Alder - til at forlade Iandet eller lade sig naturalisere. Samtidig våges der omhyggelig over Indvandringen fra Danmark. Alle siden 1863 fødte Mænd fra Kongeriget, som er danske Statsborgere, over $20 \AA \mathrm{r}$ gamle og har varigt Ophold $\mathrm{i}$ Nordslesvig, tvinges ligeledes til at forlade Landet eller lade sig naturalisere. Der tages ingen Hensyn til Veclkommendes danske Militærforhold, og flerårigt Tyendeforhold fortolkes som "varigt Ophold“.

Den preussiske Regerings hensynsløse Optræden mod Optanterne strakte sig til flere Områder. Under Henvisning til "Patent af 5. Novbr. 1841" forbød Lokaløvrig- 
hederne pludselig i Foråret 1883 alle danske Statsborgere at gifte eller bosætte sig i Nordslesvig uden særlig Tilladelse. Det nævnte Patent udstedtes i sin Tid af Hensyn. til Fattigvæsenet og under udtrykkelig Henvisning til de i så Henseende da besti̊ende strængere Bestemmelser i. Nabolandene. Det gik bestemt ud fra, at Giftermåls- eller. Bosættelsestilladelse kun kunde nægtes straffede Personer,. unge Mænd, som havde unddraget sig Værnepligten ved. at tage til Udlandet, og Folk, som måtte antages at ville falde Fattigvæsenet til Byrde. Ansøgere fik derfor altid tidligere den ønskede Tilladelse, ni̊r de kunde forevise et. Hjemstedsbevis og havde deres Militærpapirer i Orden. Det var Preusserne forbeholdt at benytte Patentet i nationalpolitiske Øjemed. Patentets vigtigste Bestemmelser inde-holdes i § 1, der forbyder Udlændinge at bosætte sig $i$. Landet uden Øvrighedens udtrykkelige Tilladelse $\mathrm{og}$ i. 5 og 6, som strængt forbyder Præsterne at ægtevie Udlændinge, der ikke har Tilladelsesbevis fra Øvrigheden. Det havde ialt 16 Paragraffer, men for at give det en til. Opnåelse af nye Formål brugelig Form ophævede Regelingen først i Firserne dets 10 sidste Paragraffer, mens. dets 6 første Paragraffer uforandrede blev stiende ved Magt. Siledes til Veje bragtes det Retsgrundlag, som i de sidste 6 År har berettiget Lokaløvrighederne til at forbyde danske Statsborgere at gifte og bosætte sig, ja endog. at skifte fast Opholdssted i Sønderjylland. Kun rent undtagelsesvis har Landråderne givet Ansøgere den ønskede. Tilladelse. Reglen har været Nægtelser: uden nærmere Motivering. Betegnende er følgende af Landråden i Sønderborg brugt Form for Afslag: „På Deres Ansøgning af .... svarer jeg Dem, idet jeg tilbagesender. det hosliggende: 
Hjemstedsberis, at jeg ikke har kunnet finde nogen Anledning til at give Dem Tilladelse til at indgå Fgteskab her i Landet."

De danske Undersaitters sørgelige Stilling i Nordslesvig fremkaldte Varren 1883 opsigtvækkende Forhandlinger i Landdagen $0 \mathrm{~g}$ Rigsdagen. I den preussiske Landdag bragte Hans Lassen Sagen frem under Finanslovens tredie Behandling. Han gav en virkelighedstro Skildring af Lokaløvighedernes hensynsløse Færd og påviste, at den ikke blot stred mod Regeringens hidtilvarende Fremgangsmåde men ogsi mod internationale Overenskomster. Endvidere ankede han over, at Provinsregeringen nægtede at optage ældle Optanter i preussisk Undersåtsforhold, på samme Tid som Sønnerne blev tvungne til. at lade sig naturalisere, hvis de vilde blive i Landet. Han bad Indemigsministeren sørge for, at disse Misforhold blev afhjulpne.

Indenrigsminister Puttkamer beklagede, at Spørgsmålet ikke var kommen frem i Form af en Interpellation. Da lan ikke havde anet dets Fremkomst, var han ikke forsynet med det fornølne Materiale. Imidlertid vilde han svare efter Asrne. Med Hensyn til Optanternes Optagelse i preussisk Undersåtsforhold forelå der ikke Vanskeligheder af principiel Art. . Tvertimod havde den tagne Forholdsregel netop til Hensigt at fi Befolkningen til at valge mellem Danmark og Prenssen som virkelig Hjemstedsstat. Forholdene i Nordslesvig var efter Hånden blevne utålelige, idet Optionen havde skabt en Stat i Staten. De fem nordslesvigske Kredse: Haderslev; Ảbenri̊, Sønderborg, Tønder og Flensborg havde ialt 250,000 Indbyggere, livoraf 25,000 - altsi̊ $1 / 10$ - var danske Undersåtter. I enkelte Distrikter var endog indtil $24 \%$ af Befolkningen Udlæendinge 
- et Forhold, som en moderne Kulturstat ikke kunde leve i. Den af Lassen påankede Forholdsregel havde ikke Karakter af Terrorisme og Vilkarlighed, men af vel overrejet Statsinteresse. "Vi bringer" - fremhævede Ministeren skarpt - „på en vis Måde vore nordsiesvigske Medborgere til en ny Option; vi stiller dem endnu en Gang foran Spørgsmålet endelig dog efter 19 Års Forløb at beslutte sig til ved Valget af Undersitsforhold at tage den Stats Interesse med i Betragtning, i hvilken de lever." I øvrigt håbede Ministeren, at Sagen senere vilde komme på Tale i Rigsdagen, hvor den var bleven ham bebudet af den Deputerede Johaninsen, og, tilføjede han, "det er meget behageligt for os; vi kan kun ønske, at disse Ting blive offentlig drøfterle."

Ministeren fik sit Ønske opfyldt. Med Sesessionisternes og Fremskridtspartiets Hjælp stillede Guistav Johannsen kort efter en Interpellation i Rigsdagen angående Lokalørighedernes Optræden mod de danske Undersaitter i Nordslesvig. Da Interpellationen stod på Dagsordenen, erklærede Rigskanslerens Repræsentant Finansminister Scholz imidlerticl til almindelig Forbavselse; at Regeringen ikke vilde besvare den, og idet Johannsen fik Ordet, forlod alle Forbundsri̊dets Medlemmer Salen på en meget opsigtvækkende Made. Johannsen gav en Fremstilling af Forholdenes Udvikling i Nordslesvig og dvælede særlig ved Pragfredens Indflydelse på Optionen. Han angreb derpå skarpt de nye Forholdsregler og påviste deres sørgelige Følger for Optanterne ved at fremføre en Række Eksempler. Der fulgte en kort Debat, i hvilken Windthorst og Richter deltog; begge, men især den sidstnævnte, kritiserede stærkt Regeringens Optræden. Forbundsrådets Medlemmer holdt 
sig imidlertid borte, til Debatten var endt. Minister Puttkamers Ord: - „det er behageligt for os, at Sagen vil komme på Tale i Rigsdagen" - holdt ikke Stik. Og det gik desværre ikke bedre med hans højtidelige Forsikringer' on, at de nye Forholdsregler i Nordslesvig kun tilsigtede at stille Optanterne overfor en ny Option. En ny Option! - det var netop, hvad Optanterne i Retfærdighedens Navn forlangte, men både før og efter den Dag har ProvinsRegeringen i Slesvig givet Hundreder af Optanter Afslag på deres Ansøgninger om Optagelse i preussisk Undersåtsforhold, og i enkelte Tilfælde har Afslaget endog været ledsaget af en Udvisningsordre.

I Året 1884 tildrog Optantspørgsmålet sig atter almindelig Opmærksomhed. Der blev foretaget en lang Række hensynsløse Udvisninger af ældre bosatte Optanter. De fleste af disse Udvisninger motiveredes med, at de Udvistes Pårørende havde deltaget $i$ statsfjendtlige Demonstrationer o: Lystrejser til Dammark, og de blev først ret forståelige, da Overpræsidenten på given Anledning erklærede, at hvad Regeringen tilsigtede ikle var at ramme enkelte Skyldige men at nedsla den danske Opposition i Nordslesvig. Siden har Udvisningerne været. talrige, ${ }^{g} g$ det skal fastslås, at de på enkelte Undtagelser nær kuß bliver forståelige, når de ses fra dette Synspunkt.

Udvisning er altid en hård Straf, selv når den rammer en Fremmed, der ikke har slået Rod i det Land, hvoraf han udvises, for den vil så godt som altid kuldkaste Fremtidsplaner $0 \mathrm{~g}$ bringe stort økonomisk Tab - om ikke ligefrem Ruin. Men hvor Udvisningerne - som i Nordslesvig - fortrinsvis rammer Familiefædre, der er født, har levet hele deres Liv, har hele deres Slægt og alle 
deres Venner i det Land, hroraf de for bestandig udvises, dér bliver Straffen en af de hårdeste og ubarmhjæertigste, vor Tid kjender. Og dog tillader Preussernes Retsfølelse, at Regeringen udviser skyldfrie Personer for derved at opni helt andre efterstrebte Formial!

Udvisningerne er pil Grund af Optanternes T'alrighed en Kræftskade for Nordslesvig. De har ødelagt mange Individers Velfærd og Livslykke, dertil skabt en Usikkerhed, som naturligvis først og fremmest Optanterne men dernæst også Landets Borgere lider under. Ingen fremmed Statsborger er sikker pâ at nyde Frugten af sit Arbejde, især nar han først kan vente den efter flere Års Forløl). Bevidstheden herom lammer i høj Grad Optinternes Foretagsomhed. Der sidder Hundreder af unge dygtige Landmænd i Nordslesvig; som ilke tør rejse nye Bygninger; foretage større Grundforbedringer eller kaste sig over et tidssvarende intensivt Landbrug af Frygt for Udvisning. Og hrem tør under slige Tilstande indlade sig pi større industrielle Foretagender!

Udvisningerne lar i Forbindelse mel de stadlig stedfindende Nægtelser af Bosættelsestilladelse haft højst uheldige Følger for Landets Borgere, bl. a. fordi de har tvunget Ejendomspriserne betydeiigt ned. Da Markedet blev lukket for dansk-fødte Kjøbere, mâtte Efterspørgslen selvfølgelig blive mindre, pa samme Tid som Tilbudet blev stør're. I skonomisk Henseende er Landbruget ogsin $\mathrm{i}$ de senere Å. bleven hairdt rummet af en systematisk Udvisuing af dauske Mejerister, men alle Hensyn mâ vige for, livar Regeringen fincler er i "Statens Interesse".

Optanterne i Nordslesvig har de samme Pligter som preussiske Statsiborgere - de må bære de samme Skatte- 
byrder og underkaste sig Landets Love - men de har ingen Rettigheder. Menighedsloven indrømmer dem ganske vist kirkelig Valgret, for så vilt de hører til Folkekirken, og den har de øvet en lang Årrække, men på et Par nordslesvigske Gejstliges Tilskyndelse ophævedes den for nogle Ar siden ved en ministeriel Anordning af Kultusminister Goszler. Og nu har de over Hovedet ingen Valgret end ikke kommunal, uagtet de stundom udgjør over Halvdelen af Kommunens Skatteydere. Deres Stilling er i alle Henseender meget sørgelig, og da de udgjør en stor Del af den nordslesvigske Befolkning, lider hele Landsdelen stærkt derunder.

Man savner endnu en bestemt Opgivelse af, hvormange Optanter der findes i Nordslesvig. Minister Puttkamer erklærede, som alt fremhævet, 1883 i Landdagen, at ca. 25,000, altsa $1 / 10$ af Befolkningen $i$ de fem nordslesvigske Kredse var danske Statsborgere, men da der kun findes fa Optanter $\mathrm{i}$ den sydlige Del af Flensborg og Tønder Amter, stâr i Virkeligheden langt over en Tiendedel af Befolkningen $i$ det egentlige Nordslesvig efter den preussiske Opfattelse i dansk Undersåtsforhold. For at fa et tilnærmelsesvis rigtigt Overslag over Forholdet mellem danske og tyske Statsborgere i den bosatte Del af Befolkningen har jeg i Januar 1889 optaget efterfølgende Statistik, som gjør Krav pa at være nøjngtig. Statistikken omfatter de sundevedske Sogne: Dybbøl, Sottrup, Ullerup, Nybøl og til Dels Broager, ialt 12 Kommuner. Statsembedsmænd er ikke medtagne. 
De nordslesvigske Optanter.

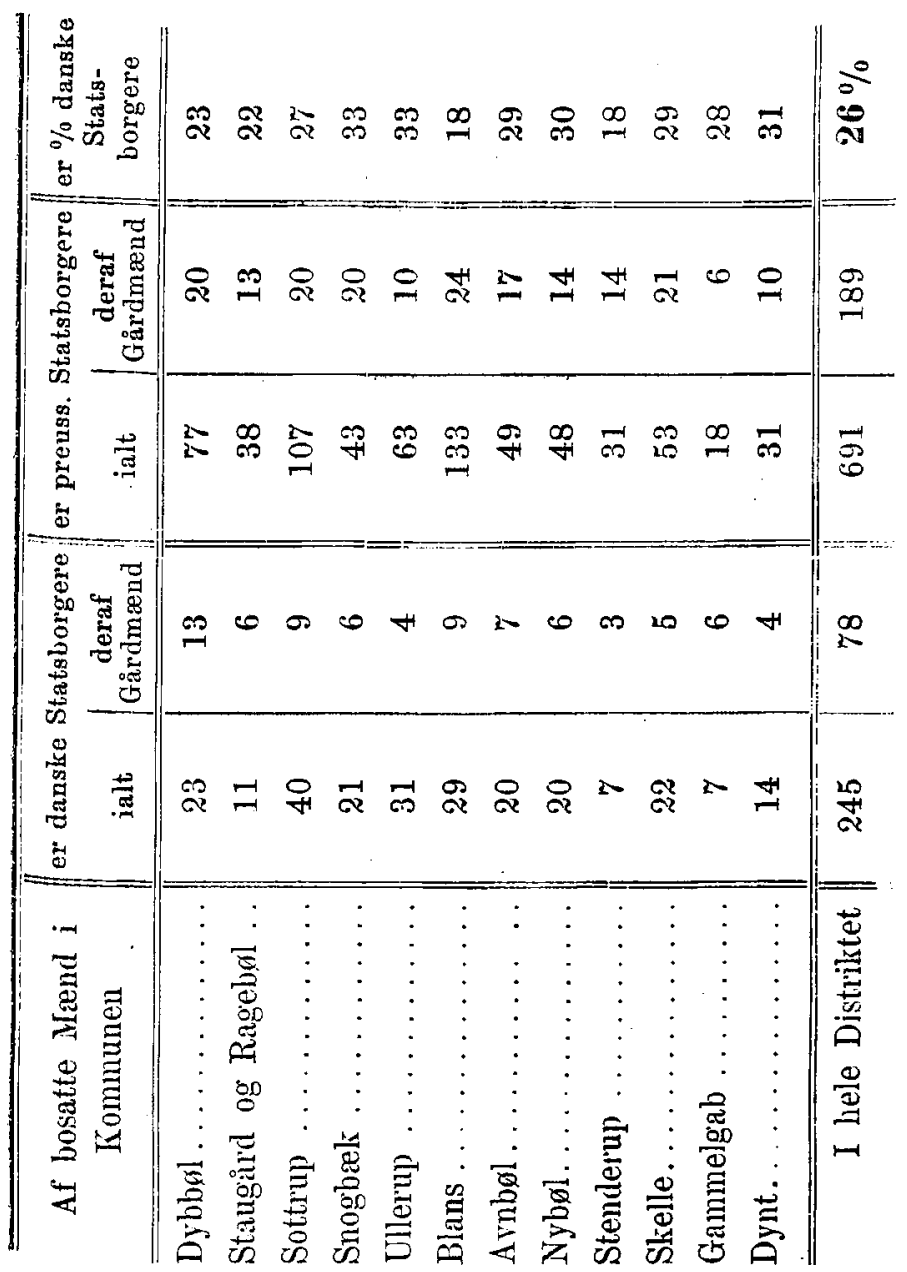

I disse sundevedske Landsbyer er, som man ser, fra $18-33 \%$, i Distriktet som Helhed over $26 \%$ af bosatte Mænd danske Statsborgere. Tager man Gårdmændene særskilt, forværres Forholdet yderligere. Af dem er $\mathrm{i}$ de enkelte Byer fra 18-50\%, i Distriktet som Helhed $29 \%$ danske Statsborgere. Det er Optionens Følger! 
Hror utrolig det end lyder, stiller Forholdene i Nordslesvig sig dog således, at det Distrikt, som Statistikken omfatter, efter min Mening kan giælde for normalt. Lxngere syd og vest på findes der ganske vist.firre Optanter, men længere nordp̊ og da.især i Grænsesognene til Gjengjæld langt flere. Som Bevis tjener følgende Statistik over Grænsesognene Aller og Skrave i Haderslev Amt.

\begin{tabular}{|c|c|c|c|}
\hline $\begin{array}{c}\text { Af bosatte Mænd } \\
\text { i Sognet }\end{array}$ & $\begin{array}{c}\text { er danske } \\
\text { Stats- } \\
\text { borgere }\end{array}$ & $\begin{array}{c}\text { er preussiske } \\
\text { Stats- } \\
\text { borgere }\end{array}$ & $\begin{array}{c}\text { er } \% \text { danske } \\
\text { Stats- } \\
\text { borgere }\end{array}$ \\
\hline Aller' & 63 & 106 & 37 \\
\hline Skrave. & 47 & 72 & 39 \\
\hline
\end{tabular}

I ikke fa af Haderslev Amts Landsbyer, f. Ex. i Langetved og Arnum er over $40 \%$ af bosatte Mænl - og mange Steder er over $50 \%$ af Garrmand danske Statsborgere. Undtagelsesvis kjendes ogsi disse Forhold længere sydpa. I Landsbyen Stevning pi Als er f. Ex. $43 \%$ af bosatte Mænd danske Statsborgere.

I den sydlige Del af Åbenri Amt er Forholdet bedre. I Kliplev Sogn er kun $23 \%$ af bosatte Mænd danske Statsborgere, uagtet det er et af de mest dansksindede Sogne på dette Strøg. Det mindste Antal danske Statsborgere $\mathrm{i}$ et enkelt nordslesvigsk Sogn, nemlig $16 \%$, har jeg truffet i Emmerlev, et af de sydligste dansksindede Sogne i Tønder Amt.

Pa Grundlag af disse statistiske Oplysuinger kan man med temmelig stor Sikkerhed sige: I Sognene nord for Flensborg-Tonder Linjen er hyppigere over 30 end under $20 \%$ - i Reglen over $25 \%$ af bosatte Wænd danske Statsborgere. 
Minister Puttkamer har Ret i, at det ikke sømmer sig for en moderne Kulturstat at opretholde sia abnorme For1old. Den preussiske Regering bør derfor snarest mulig hidføre sundere Tilstande. Preussens ledende Statsmænd erefter at de har erklæret Pragfredens $\S 5$ for ophævet moralsk forpligtede til at stille Optanterne orerfor et ny Talg, som, da det vil forega under helt andre Forudsetninger, ogs̊ vil føre til et helt andet Resultat. Kun derved vil man fả en endelig Løsning på det ulykliebringende Optantspørgsmål.

De nordslesvigske Repræsentanter har for ikke længe siden indbragt følgende Forslag i den preussiske Landdag for om mulig at bevæge Regeringen til dette Skridt:

"Landargen beslutter at anmode den $\mathrm{kgl}$. Statsregering om at indstruere Regeringen i Slesvig til nu at optage som preussiske Statsborgere Personer fra Hertngdømmet Slesvig, der i Medfor af Wienerfreden af 30. Octbr. 1864 har opteret for Danmark, of ligeledes sådanne, som forinden 11.0 octbr. 1878 er lrste fra det prenssiske Undersåtsforhold, när de er vendte tilbage til deres gamle Hjemland eller onske at vende tilbage dertil og søger om Optagelse i preussisk Undersätsforhold, samt til i militær Henseende at stille de Gjenoptagne i Lighed med de Aldersklasser, hrortil de hører." *)

Forslaget tager, som man ser, også Hensyn til de unge Sønderjycler, der er udvandrede i 'lillid til Pragfredens $\$ 5$ efter d. 16. Novbr. 1870. Det er ikke mere, end hrad Billighed kræver, thi ogsa de er blevne hairdt skuffede og er derfor endnu landflygtige.

") Landdagen blev mod Forventning sluttet d. 30. April, og Forslaget, som navnlig støttes af Centrum, vil derfor først komme frem i næste Samling. 
De i det nævnte Tidsrum på lovlig Måde*) udvandrede unge syttenårige Sønderjyder udgjør henved 4000 . Udvandringen fordeler sig således p̊̊ de forskjellige Å:

\begin{tabular}{lcc|ccc}
1871 & udvandrede & - & 1875 & udvandrede & 744 \\
1872 & - & 277 & 1876 & - & 687 \\
1873 & - & 477 & 1877 & - & 589 \\
1874 & - & 699 & 1878 & - & 411
\end{tabular}

Som Bevis på hvilken Indflydelse Pragfredens $\S 5$ har haft på denne Udvandring kan fremhæves, at der i 1879 kun udvandrede 247 syttenårige Sønderjyder, uagtet Traktaten af 11. Octbr., som bekjendt, først blev offentliggjort i Februar $18 \% 9$.

Hvis den preussiske Regering fremdeles vægrer sig ved at hidføre en ny Option, vil Optantspørgsmålet volde endinu flere Bryderier. Efter preussisk Statsret stir nemlig Optanternes Børn i uendelige Led udenfor preussisk Statsborgerforhold, med mindre de naturaliseres eller for Kvindernes Vedkommende indgår Æłgteskab med preussiske Borgere. Men efter dansk Statsret er ingen af Optanternes efter Optionen fødte Børn danske Statsborgere. $\mathrm{Nu}$ tvinger den preussiske Regering ganske vist Mændene til at forlade Landet eller lade sig naturalisere, efter Hånden som de når den værnepligtige Alder, men ikke alle Kvinder blive gifte. Allerede nu findes der Tusinder af Børn, Kvinder og unge Mænd i Nordslesvig, som star

4) Ved Siden af denne på lovlig Mâde foregåede Udvandring har der i Halvfjerdserne fundet en stærk Desertion Sted fra Nordslesvig særlig til Amerika. Man overdriver sikkert ikke, når man siger, at 3 à 400 værnepligtige Nordslesvigere årlig har forladt Landet uden $\emptyset$ vrighedens Tilladelse. 
uden for ethvert Statsborgerforhold, og flere fødes så at sige daglig.

Fra hvad Side man end ser Optantspgrgsmålet frembyder det store Skyggesider. De nuværende Forhold er i enhver Henseende højst forkastelige. De er. en Ulykke for Tusinder og atter Tusinder Fanilier og til ubodelig Skade for Nordslesvig. Gid Retfærdigheden derfor snart må ske Fyldest. Gid Optanterne, som uforskyldt er komne i denne sørgelige Stilling, fordi de havde for høj en Mening om Traktaters Betydning, for god en Tro til Statsmænds Ord, snart må blive stillede overfor en ny Option. 